\title{
Diversity of Herbaceous Plant in The Utilization Block of Sumber Agung Tahura Wan Abdul Rachman Bandar Lampung
}

\author{
Widia Paramita*, Yulianty, Bambang Irawan, Suratman \\ Jurusan Biologi FMIPA Universitas Lampung \\ JI. Prof. Soemantri Brodjonegoro, No 1, Bandar Lampung 35145 \\ *E-mail: widiaparamita96@gmail.com
}

\begin{abstract}
Diversity is a variety of species that are similarly formed and the abundance of a species. The purpose of this study is to determine the diversity and characteristics of herbaceous plants in Sumber Agung Resort Bandar Lampung Wan Abdul Rachman (WAR) forest park. The method used is a purposive sampling method at several points, done by direct observation using the Belt Transect method with plot size $1 \times 1 \mathrm{~m}^{2}$ with a distance between plot $100 \mathrm{~m}^{2}$ then the picture of herbaceous plants taken as documentation material. The species is then taken for identification regarding some literature. Data analysis by measuring the parameters of vegetation using the analysis of density and frequency variables which then determine the Importance Value Index (INP). Observation of herbaceous plants was done by identifying and making herbarium. The results of the study are, there are 45 species of herbaceous plants that have been identified, consisting of 22 families. The highest density of herbaceous species that are found belongs to Asteraceae, Solanaceae, Araceae, Poaceae, Zingiberaceae, and Euphorbiaceae. Characteristics of herbaceous growth are influenced by air temperature, soil moisture, and soil $\mathrm{pH}$. The highest Important Value Index (INP) in herbaceous plants belongs to Family Poaceae; Lophatherium gracile with an important value index (INP) $31.43 \%$.
\end{abstract}

Keywords: Diversity, Herbaceous Plants, Wan Abdul Rachman Forest Park (WAR), Importance Value Index (INP).

\section{PENDAHULUAN}

Indonesia merupakan negara dengan tingkat keanekaragaman flora yang tinggi, kekayaan alam Indonesia menyimpan berbagai jenis flora yang tumbuh liar di hutan. Menurut data Dinas Kehutanan Provinsi Lampung (2006) diketahui bahwa vegetasi yang terdapat di kawasan hutan di Provinsi Lampung cukup banyak jenisnya, baik di kawasan taman nasional maupun hutan lindung. Setidaknya terdapat jenis tumbuhan mulai dari pohon, herba, liana, vegetasi bawah, dan lain-lain (Arsyah, 2014).

Taman Hutan Raya (Tahura) Wan Abdul Rachman terletak di Provinsi Lampung yang secara geografis terletak diantara 05'18' sampai $05^{\circ}$ 29'LS dan $105^{\circ} 02^{\prime}$ sampai $105^{\circ} 14^{\prime} \mathrm{BT}$, serta memiliki luas wilayah 22.249 ha. Tahura Wan Abdul Rachman yang terletak di Provinsi Lampung dengan luas sekitar 22.249 ha memiliki keanekaragaman jenis tanaman. Tahura Wan Abdul Rachman dibagi menjadi beberapa blok, salah satunya blok pemanfaatan tepatnya di Sumber Agung Resort Bandar Lampung, seluas $\pm 549,76$ ha yang merupakan blok yang di gunakan untuk kegiatan pendidikan, penelitian dan wisata alam (Dinas Kehutanan Provinsi Lampung, 2006). Keanekaragaman pohon di Taman Hutan Raya (Tahura) Wan Abdul Rachman telah banyak dikaji sebelumnya. Sementara penelitian terhadap diversitas dan karakteristik tanaman herba belum banyak dilakukan, demikian pula identifikasi terhadap tumbuhan herba. Menurut Tjitrosoepomo (2003), jenis-jenis tumbuhan herba yang tumbuh liar cenderung terabaikan. Ada beberapa cara untuk melakukan identifikasi tumbuhan herba. Pertama dan yang penting adalah adanya spesimen yang segar mengingat ciri tumbuhan herba dapat dilihat dari 
batangnya yang lunak dan berair. Untuk identifikasi bagian penting adalah bunga dan biji, termasuk ukuran dan warnanya. Selain itu perlu diketahui pula bagian tumbuhan herba yang dapat dimanfaatkan. Ciri vegetatif yang perlu diperhatikan dalam identifikasi tumbuhan herba yaitu berupa daun, pucuk daun dan akar. Selain itu dapat juga dilihat dari macam-macam getah, bentuk daun dan susunannya.

Tumbuhan herba mempunyai peran penting untuk menjaga keseimbangan ekosistem yakni berperan sebagai tumbuhan penutup tanah. Tumbuhan ini tumbuh di antara pepohonan yang utama dan tumbuhan herba berperan dalam memperkuat struktur tanah hutan tersebut.

Tumbuhan penutup tanah dapat berfungsi sebagai peresapan dan membantu menahan jatuhnya air secara langsung. Selain itu tumbuhan penutup tanah dapat berperan dalam menghambat dan mencegah erosi yang berlangsung secara cepat. Tumbuhan ini dapat menghalangi jatuhnya air hujan secara langsung, mengurangi kecepatan aliran permukaan, mendorong perkembangan biota tanah yang dapat memperbaiki sifat fisik dan kimia tanah serta berperan dalam menambah bahan organik tanah sehingga menyebabkan resistensi tanah terhadap erosi (Maysaroh, 2010). Mengingat potensi tumbuhan herba yang belum banyak dikaji di Blok Pemanfaatan Sumber Agung Resort Tahura Wan Abdul Rachman Lampung maka perlu dilakukan penelitian tentang potensi diversitas dan karakteristik tumbuhan herba yang berpotensi di area kawasan tersebut.

\section{METODE PENELITIAN}

Penelitian ini dilakukan di Blok Pemanfaatan Sumber Agung Resort Tahura Wan Abdul Rachman Lampung. Pengambilan sampel dilakukan pada Januari sampai Maret 2018 dan identifikasi tumbuhan dilakukan di Laboratorium Botani FMIPA Unila.

Alat-alat yang digunakan dalam penelitian ini adalah kamera SLR, alat tulis, meteran, tali rafia, peta dasar Tahura, gunting, lakban, oven, kantong plastik, kertas karton, kertas koran,kertas buram, selotip, lem, pensil 2B, etiket gantung, buku identifikasi yaitu buku Flora of Malaya (Holtum, 1989), Taksonomi Tumbuhan (Tjitrosoepomo, 2003), dan Flora (Steenis dan Van, 2006), serta buku Cronquist (1981). Bahan yang digunakan pada penelitian ini adalah tumbuhan herba yang ditemukan pada daerah pengamatan, tally sheet, kapas, dan alkohol $70 \%$.

\section{Studi Pendahuluan}

Studi pendahuluan dilakukan pada Oktober 2017. Kegiatan ini bertujuan untuk menentukan lokasi pengamatan keanekaragaman dan pola distribusi tumbuhan herba di Unit Sumber Agung Resort Bandar Lampung Tahura Wan Abdul Rachman Lampung.

\section{Pengamatan di Lapangan}

Penentuan lokasi dilakukan menggunakan metode purposive sampling yaitu berdasarkan keberadaan tumbuhan herba yang dianggap mewakili tempat tersebut (Fachrul, 2007). Pengamatan dilakukan secara langsung menggunakan metode belt transek. Menurut Fahrul (2007), belt transek adalah jalur sempit melintang pada lahan tempat dilakukan pengamatan. Agar sampel tumbuhan yang terambil merata, zona pemanfaatan seluas $10 \mathrm{~km}$ dibagi menjadi 10 titik pengamatan artinya luas area pengamatan adalah $1 \mathrm{~km}$ per titik pengamatan. Kemudian pada masingmasing titik pengamatan diletakkan garis transek dengan panjang per transek 100 $m$ dengan jumlah transek yaitu 10 transek. Sepanjang garis transek dibuat plot masing-masing dengan ukuran $1 \times 1 \mathrm{~m}$ dan lokasi plot yang dipilih secara acak. 


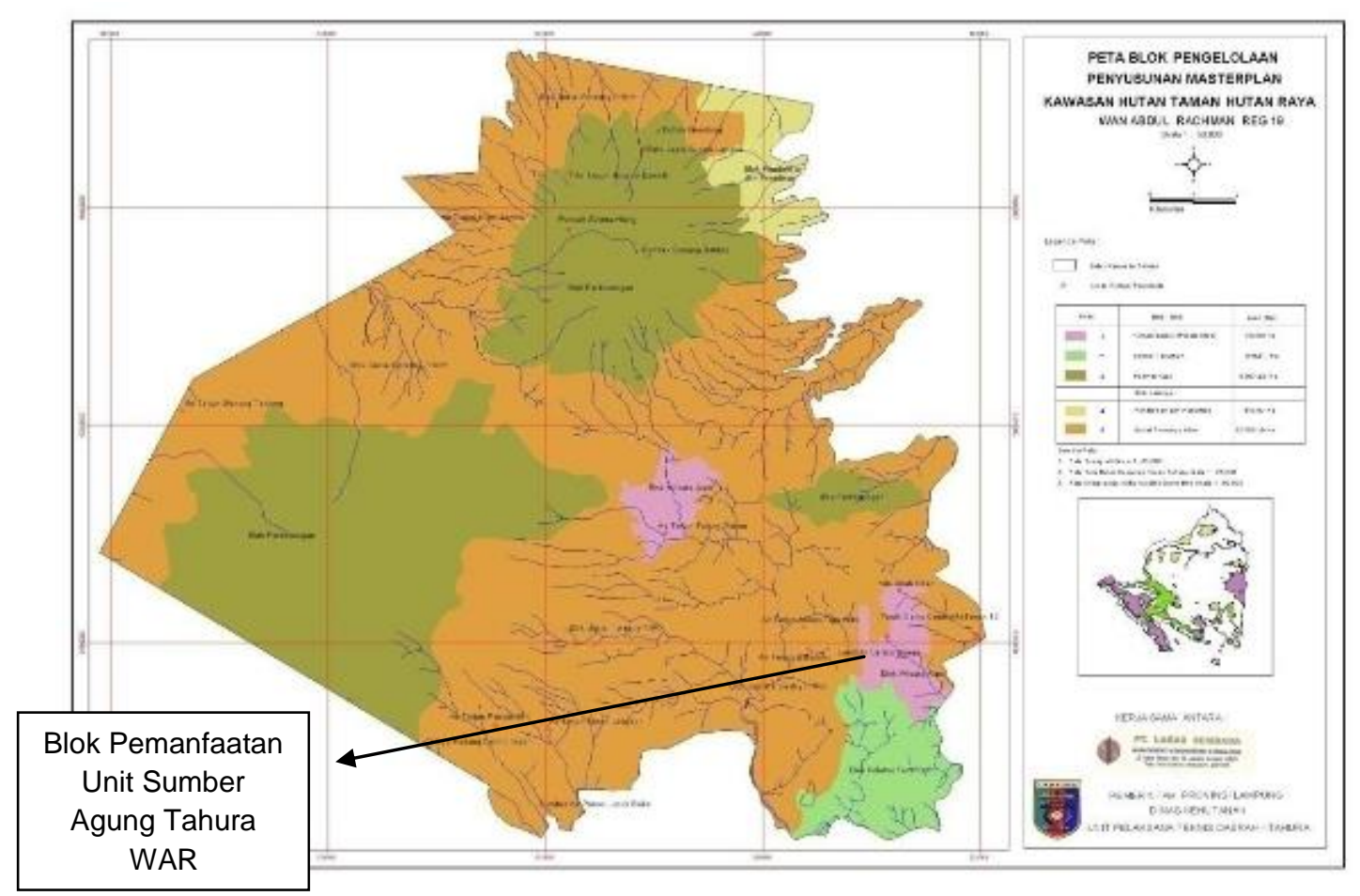

Gambar 1. Peta Lokasi titik penelitian di blok pemanfaatan Unit Sumber Agung Tahura Wan Abdul Rachman

Analisis transek adalah teknik untuk memfasilitasi peneliti dalam pengamatan lingkungan dan keadaan sumberdaya dengan cara berjalan menelusuri wilayah tempat mereka tinggal pada suatu lintasan tertentu yang sudah disepakati. Dengan teknik analisis transek diperoleh gambaran keadaan potensi sumber daya alam masyarakat beserta masalahmasalah, perubahanperubahan keadaan dan potensi-potensi yang ada (Heddy, Soemitro, dan Soekartomo, 1986).

Transek sebagai jalur sempit melintang lahan yang akan dipelajari dan diselidiki. Tujuannya adalah untuk mengetahui hubungan perubahan vegetasi dan perubahan lingkungan, atau untuk mengetahui jenis vegetasi yang ada di suatu lahan secara cepat. Dalam hal ini, apabila vegetasi sederhana maka garis yang digunakan semakin pendek. Analisis vegetasi di hutan, panjang jalur transek yang digunakan sekitar $50 \mathrm{~m}$ sampai 100 $\mathrm{m}$. Sedangkan untuk vegetasi semak belukar jalur transek yang digunakan cukup $5 \mathrm{~m}$ sampai $10 \mathrm{~m}$, dan untuk vegetasi yang lebih sederhana, maka garis yang digunakan cukup $1 \mathrm{~m}$ (Ramazas, 2012).

\section{Tahap Pengambilan Data}

Pengambilan data dilakukan secara langsung yaitu dengan cara menghitung jumlah individu spesies tumbuhan herba yang ada dalam plot kemudian dimasukkan dalam tabel data dan dicatat deskripsi setiap tumbuhan herba yang ditemukan.Pengambilan data penelitian meliputi :

1. Data primer; data diperoleh dari perhitungan jumlah tumbuhan herba yang didapat dari setiap plot dengan menggunakan metode transek.

2. Data sekunder; data diperoleh secara tidak langsung. Data sekunder yang diambil meliputi keadaan umum lokasi penelitian

\section{Pengambilan Data di Laboratorium.}

Identifikasi tumbuhan herba dilakukan dengan membuat herbarium di Laboratorium Botani Jurusan Biologi Fakultas Matematika Dan IImu Pengetahuan Alam, Universitas Lampung.

\section{Analisis Data}

Pengukuran parameter vegetasi berdasarkan variabel kerapatan, dominasi, dan frekuensi yang selanjutnya diperlukan untuk menentukan indeks nilai penting (INP). 


\section{HASIL DAN PEMBAHASAN}

Hasil penelitian menunjukkan bahwa terdapat 45 spesies dari 22 suku tumbuhan herba di Blok Pemanfaatan Sumber Agung Resort Tahura Wan Abdul Rachman Lampung.

Tabel 1. Tumbuha Herba Di Blok Pemanfaatan Sumber Agung Resort Tahura Wan Abdul Rachman Lampung

\begin{tabular}{|c|c|c|c|}
\hline No & Suku & Nama Lokal & Nama IImiah \\
\hline \multirow[t]{10}{*}{1} & Asteraceae & Bandotan & Ageratum conyzoides \\
\hline & & Jotang Kuda & Synedrella nodiflora \\
\hline & & Jalantir & Conyza sumantrensis \\
\hline & & Jabung & Siegesbeckia orientalis \\
\hline & & Rumput Minjangan & Chromolaena odorata \\
\hline & & Kenikir & Cosmos caudatus \\
\hline & & Tapak Liman & Elephantopus scaber \\
\hline & & Sawi langit & Vernonia cinerea \\
\hline & & Sintrong & Crassocephalum crepidioides \\
\hline & & Sambung Rambat & Mikania micranta \\
\hline \multirow[t]{5}{*}{2} & Solanaceae & Takokak & Solanum torvum \\
\hline & & Terong & Solanum melongena \\
\hline & & Ranti & Solanum torvum \\
\hline & & Cabai & Capsicum annuum \\
\hline & & Ciplukan & Physalis angulata \\
\hline \multirow[t]{3}{*}{3} & Araceae & Talas & Colocasia esculenta \\
\hline & & Suweg & Amorphophallus sp. \\
\hline & & Daun Bahagia & Dieffenbachia seguine \\
\hline \multirow[t]{3}{*}{4} & Euphorbiaceae & Meniran & Phyllanthus niruri \\
\hline & & Patikan Kebo & Euphorbia hirta \\
\hline & & Anting Anting & Acalypha australis \\
\hline \multirow[t]{3}{*}{5} & Poaceae & Rumput Bede & Brachiaria decumbens \\
\hline & & Rumput Gajah & Pennisetum purpureun \\
\hline & & Rumput Bambu & Lophatherium gracile \\
\hline \multirow[t]{3}{*}{6} & Zingiberaceae & Lengkuas & Alpinia galnga \\
\hline & & Kunyit & Curcuma longa \\
\hline & & Pacing & Costus speciosus \\
\hline \multirow[t]{2}{*}{7} & Acanthaceae & Rumput Israel & Asystasia gangetica \\
\hline & & Pletekan & Ruellia tuberosa \\
\hline \multirow[t]{2}{*}{8} & Cyperaceae & Rumput Pendul & Kyllinga brevifolia \\
\hline & & Rumput Teki & Cyperus kyllinga \\
\hline 9 & Commelinaceae & Gewor & Commelina benghalensis \\
\hline 10 & Capparidaceae & Maman & Cleoma rutidospermae \\
\hline 11 & Campanulaceae & Kitolod & Hippobroma longiflora \\
\hline 12 & Piperaceae & Suruhan & Peperomia pellucida \\
\hline 13 & Amaranthaceae & Bayam Duri & Amaranthus spinosus \\
\hline 14 & Basellaceae & Binahong & Anredera Cordifolia \\
\hline 15 & Oxalidaceae & Calincing & Oxalis barrelieri \\
\hline 16 & Asparagaceae & Andong & Cordyline fructicosa \\
\hline 17 & Verbenaceae & Pecut Kuda & Stachytarpheta jamaicensis \\
\hline 18 & Melastomataceae & Harendong Bulu & Clidemia hirta \\
\hline 19 & Apiaceae & Pegagan & Centella asiatica \\
\hline 20 & Fabaceae & Putri malu & Mimosa pudica \\
\hline 21 & Convolvulaceae & Ubi Jalar & Ipomoea batatas \\
\hline \multirow[t]{2}{*}{22} & Cannaceae & Ganyong & Canna discolor \\
\hline & 22 Suku & & 45 Jenis \\
\hline
\end{tabular}

Tabel 1 menunjukkan jumlah seluruh tumbuhan herba yang telah diidentifikasi yaitu sebanyak 45 jenis dari 22 suku. Gambar 2 berikut menunjukkan grafik persebaran suku tumbuhan herba pada lokasi penelitian. Dari gambar terlihat bahwa Suku Asteraceae memiliki jumlah kerapatan yang terbanyak pada tumbuhan herba yang telah diidentifikasi yaitu sebanyak 10 individu. 


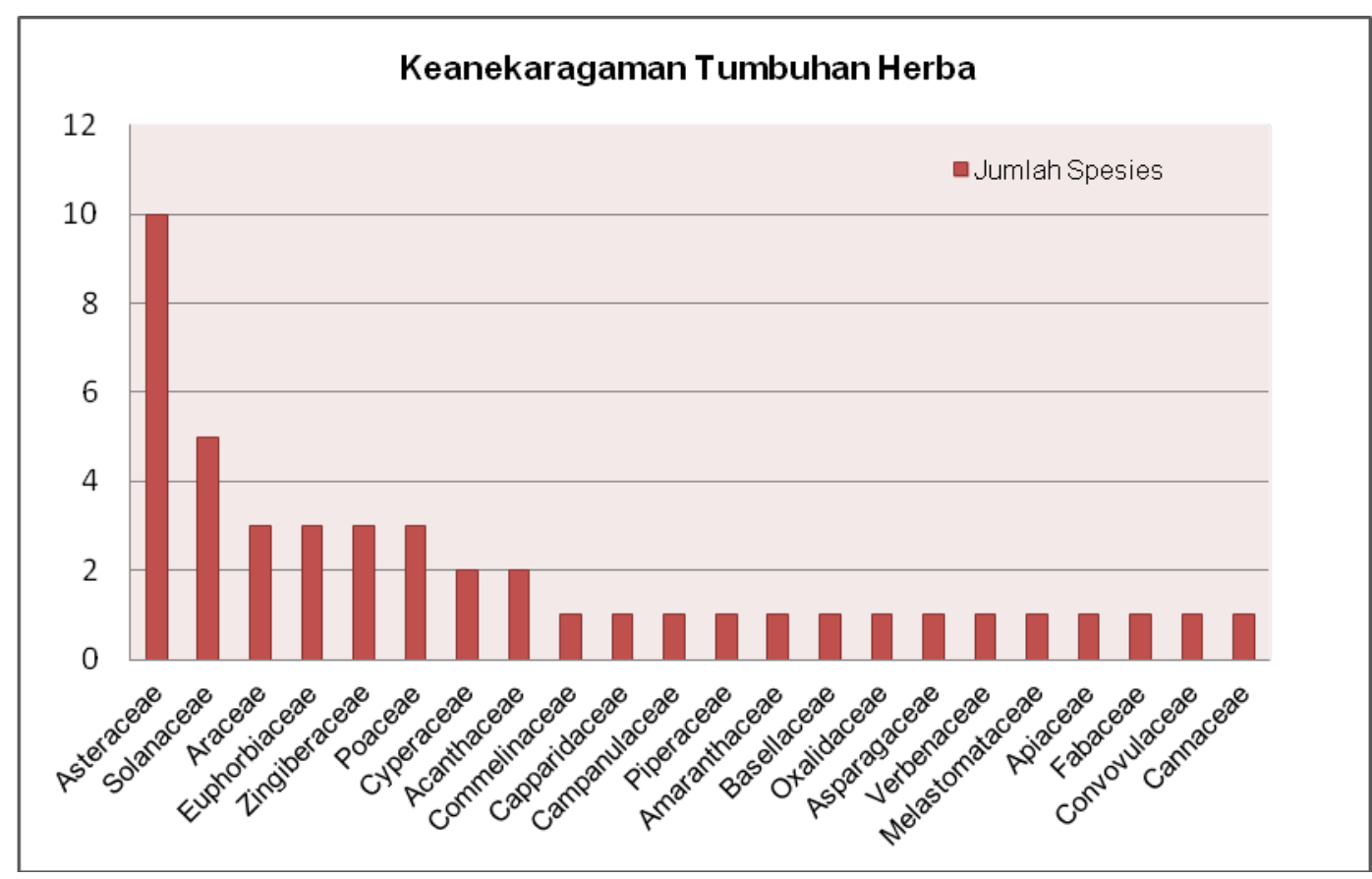

Gambar 2. Persebaran Suku Tumbuhan Herba Pada Lokasi Penelitian Blok Pemanfaat Sumber Agung Resort Tahura Wan Abdul Rachman

Suku Solanaceae merupakan suku terbesar berikutnya dengan jumlah jenis tumbuhan sebanyak 5 jenis. Kemudian Suku Poaceae, Suku Araceae, Suku Euphorbiaceae, dan Suku Zingiberaceae adalah suku terbesar selanjutnya pada tumbuhan herba yang telah ditemukan sebanyak 3 jenis tumbuhan. Dari Tabel 1 di atas juga terlihat bahwa Suku Asteraceae memiliki jenis yang terbanyak pada tumbuhan herba yang telah diidentifikasi yaitu sebanyak 10 jenis tumbuhan. Selanjutnya suku terbanyak kedua yaitu suku Solanaceae sebanyak 5 jenis tumbuhan dan suku terbanyak ketiga yaitu Suku Araceae, Suku Euphorbiaceae, dan Suku Zingiberaceae sebanyak 3 jenis tumbuhan.

Penyebaran dan pertumbuhan herba dipengaruhi oleh daya tumbuh biji, topografi, keadaan tanah, serta faktor lingkungan lainnya. Biji tumbuhan yang tersebar di daerah sedikit zat hara yang intensitas cahayanya tinggi, maka biji tidak dapat tumbuh. Jenis tumbuhan herba yang banyak terdapat di Blok Pemanfataan Sumber Agung Resort Taman Hutan Raya Wan Abdul Rachman Lampung adalah Lophatherium gracile, diikuti oleh Asystasia gangetica, lalu
Brachiaria decumbens dan Chromolaena odorata. Beragamnya jenis tumbuhan herba pada tiap plot amatan disebabkan oleh kondisi lingkungannya (Aththorick, Widhiastuti, dan Evanus, 2006). Pola penyebaran tumbuhan dalam komunitas bervariasi karena adanya beberapa faktor. Faktor yang berinteraksi yaitu angin, ketersediaan air, intensitas cahaya, kemampuan reproduksi, dan interaksi intraspesifik (kompetisi) (Wright, 2002). Hal ini dikarenakan Asteraceae merupakan jenis tumbuhan yang memang paling banyak dijumpai di Indonesia dan mayoritas tumbuhan dari Suku Asteraceae merupakan tumbuhan jenis herba. Suku Asteraceae hidup dengan memerlukan intensitas penyinaran matahari yang cukup, sehingga di daerah tropis Suku Asteraceae tumbuh dengan pesat (Ariningsih, 2009). Suku Asteraceae tumbuh secara liar dengan penyebaran biji dibantu oleh angin (anemokori). Penyebaran tumbuhan Suku Asteraceae tersebar secara meluas, sehingga keberadaannya dapat kita temukan di setiap tempat pada lokasi penelitian ini.

Suku Solanaceae merupakan suku terbanyak kedua dengan jenis tumbuhan sebanyak 5 jenis. Suku Solanaceae 
banyak dibudidayakan dan tumbuhannya banyak dimanfaatkan oleh masyarakat karena dapat mudah tumbuh di daerah tropis (Duke,2010). Suku Poaceae bersifat kosmopolit dalam penyebarannya, Suku Poaceae memerlukan penyinaran matahari langsung dengan intensitas yang tinggi. Tumbuhan dari Suku Poaceae ini biasanya ditemukan di lingkungan yang terbuka. Selain itu mereka memiliki biji yang berukuran kecil dan dilengkapi dengan rambut halus, sehingga biji mudah menyebar dengan bantuan angin maupun binatang (Ariningsih, 2009). Suku Araceae merupakan suku tanaman herba yang biasa tumbuh di daerah tropis dan subtropis. Suku Araceae dapat dengan mudah tumbuh di lingkungan yang lembab dengan kondisi tanah gembur (humus) dan subur. Selanjutnya Suku Euphorbiaceae dapat dengan mudah tumbuh di daerah tropis, Euphorbiaceae termasuk tumbuhan yang memiliki toleransi tinggi terhadap suhu udara dan intensitas cahaya matahari. Selanjutnya Suku Zingiberaceae merupakan suku terbanyak ke tiga, hal ini terjadi karena pada Suku Zingiberaceae dapat mudah tumbuh di daerah tropis dan sangat mudah dikembangbiakkan.

Berdasarkan hasil penelitian yang telah dilakukan dapat diketahui bahwa hasil Indeks Nilai Penting (INP) dari seluruh jumlah spesies tumbuhan herba dapat dilihat pada Tabel 2. Indeks Nilai Penting (INP) jenis tumbuhan pada suatu komunitas merupakan salah satu parameter yang menunjukkan peranan jenis tumbuhan dalam komunitas tersebut. Kehadiran suatu jenis tumbuhan pada suatu daerah menunjukkan kemampuan adaptasi terhadap kondisi lingkungan, jika semakin besar nilai INP suatu spesies semakin besar tingkat penguasaan terhadap komunitas dan sebaliknya (Soegianto, 1994).

Penguasaan spesies tertentu dalam suatu komunitas apabila spesies yang bersangkutan berhasil menempatkan sebagian besar sumberdaya yang ada dibandingkan dengan spesies yang lainnya (Saharjo dan Cornelio, 2011)

Adanya jenis yang mendominansi dapat dipengaruhi oleh beberapa faktor, antara lain adalah persaingan antar tumbuhan yang ada, dalam hal ini berkaitan dengan iklim, jika iklim mendukung maka jenis tersebut akan lebih banyak ditemukan (Syafei,1977).

Indeks keanekaragaman berdasarkan hasil analisis menunjukkan bahwa tingkat keanekaragaman jenis termasuk kategori tinggi. Nilai keanekaragaman yang semakin tinggi menunjukkan semakin stabil komunitas di suatu kawasan. Suatu komunitas stabil jika jumlah jenis yang ada relatif konstan atau tidak berubah (Indriyanto, 2006).

Pada Blok Pemanfataan Sumber Agung Resort Tahura Wan Abdul Rachman Lampung, komunitas tumbuhan herba menunjukkan kestabilan ekosistem yang mengindikasikan bahwa komunitas herba tidak terpengaruh pada tekanan lingkungan pada kawasan tersebut. Hal ini terjadi karena keanekaragaman tumbuhan herba sangat bervariasi pada lokasi penelitian. Dari Tabel 2 di atas dapat dilihat jumlah kerapatan terbanyak terdapat pada Suku Poaceae jenis Lophatherium gracile dengan indeks nilai penting (INP) sebesar 31,43 \%. Selanjutnya kerapatan terbanyak kedua yaitu Suku Acanthaceae jenis Asystasia gangetica dan Brachiaria decumbens dengan Indeks Nilai Penting (INP) sebesar $20,45 \%$ dan $13,73 \%$. Kemudian kerapatan terbanyak ketiga yaitu Suku Asteraceae jenis Chromolaena odorata dengan Indeks Nilai Penting (INP) sebesar $11,2 \%$. Hal ini menunjukkan kerapatan suatu suku ataupun spesies memiliki keanekaragaman jenis yang tinggi.

Selanjutnya frekuensi memiliki pola penyebaran ke seluruh kawasan titik pengamatan, hal ini terjadi karena daya penyebaran dan adaptasi terhadap lingkungan sangat baik. Penyebaran tumbuhan herba didominasi jika dominasi lebih terkonsentrasi pada satu jenis maka 
Tabel 2. Data Hasil Pengamatan Indek Nilai Penting (INP) dari seluruh jumlah spesies tumbuhan herba

\begin{tabular}{|c|c|c|c|c|}
\hline Suku & Jenis & KR\% & FR\% & INP\% \\
\hline \multirow[t]{10}{*}{ Asteraceae } & $\begin{array}{l}\text { Crassocephalum } \\
\text { crepidioides }\end{array}$ & 1,36 & 4,45 & 5,81 \\
\hline & Conyza sumantrensis & 2,87 & 1,78 & 5,54 \\
\hline & Siegesbeckia orientalis & 1,47 & 3,56 & 5,03 \\
\hline & Chromolaena odorata & 7,94 & 3,26 & 11,2 \\
\hline & Ageratum conyzoides & 3,74 & 2,37 & 6,11 \\
\hline & Synedrella nodiflora & 1,28 & 2,07 & 3,35 \\
\hline & Elephantopus scaber & 1,24 & 1,8 & 3,04 \\
\hline & Vernonia cinerea & 0,90 & 3,37 & 3,86 \\
\hline & Cosmos caudatus & 0,30 & 1,8 & 2,1 \\
\hline & Mikania micrantha & 2,45 & 2,37 & 4,81 \\
\hline \multirow[t]{5}{*}{ Solanaceae } & Solanum melongena & 0,03 & 0,59 & 0,32 \\
\hline & Solanum nigrum & 0,07 & 0,07 & 0,14 \\
\hline & Physalis angulata & 0,30 & 1,18 & 2,1 \\
\hline & Capsicum annuum & 0,03 & 0,29 & 0,32 \\
\hline & Solanum torvum & 0,03 & 0,59 & 0,62 \\
\hline \multirow[t]{3}{*}{ Araceae } & Colocasia esculenta & 0,45 & 0,89 & 1,34 \\
\hline & Dieffenbachia seguine & 0,34 & 0,89 & 1,23 \\
\hline & Amorphophallus sp. & 0,07 & 0,29 & 0,36 \\
\hline \multirow[t]{3}{*}{ Euphorbiaceae } & Phyllanthus niruri & 0,71 & 7,12 & 7,83 \\
\hline & Acalypha australis & 0,41 & 3,56 & 3,97 \\
\hline & Euphorbia hirta & 1,28 & 2,07 & 3,35 \\
\hline \multirow[t]{3}{*}{ Zingiberaceae } & Costus speciosus & 0,90 & 2,67 & 3,57 \\
\hline & Curcuma longa & 0,15 & 0,59 & 0,74 \\
\hline & Alpinia galanga & 0,11 & 0,59 & 0,7 \\
\hline \multirow[t]{2}{*}{ Acanthaceae } & Asystasia gangetica & 14,52 & 5,93 & 20,45 \\
\hline & Ruellia tuberosa & 0,37 & 2,67 & 3,04 \\
\hline \multirow[t]{2}{*}{ Cyperaceae } & Cyperus kyllinga & 1,81 & 5,34 & 7,15 \\
\hline & Kyllinga brevifolia & 6,39 & 0,89 & 7,28 \\
\hline \multirow[t]{3}{*}{ Poaceae } & Brachiaria decumbens & 11,95 & 1,78 & 13,73 \\
\hline & Pennisetum purpureum & 2,68 & 1,78 & 4,46 \\
\hline & Lophatherium gracile & 25,50 & 5,93 & 31,43 \\
\hline Commelinaceae & Commelina benghalensis & 0,30 & 1,78 & 2,08 \\
\hline Capparidaceae & Cleoma rutidospermae & 0,41 & 0,29 & 3,08 \\
\hline Campanulaceae & Isotoma longiflora & 0,37 & 2,67 & 2,15 \\
\hline Piperaceae & Peperomia pellucida & 1,39 & 3,56 & 4,95 \\
\hline Amaranthaceae & Amaranthus spinosus & 0,22 & 3,56 & 3,78 \\
\hline Basellaceae & Anredera Cordifolia & 1,05 & 4,15 & 5,2 \\
\hline Oxalidaceae & Oxalis barrelieri & 1,05 & 0,59 & 1,64 \\
\hline Asparagaceae & Cordyline fructicosa & 0,34 & 1,78 & 2,12 \\
\hline Verbenaceae & Stachytarpheta jamaicensis & 0,37 & 1,48 & 1,85 \\
\hline
\end{tabular}




\begin{tabular}{llccc}
\hline \multicolumn{1}{c}{ Suku } & \multicolumn{1}{c}{ Jenis } & KR\% & FR\% & INP\% \\
\hline Melastomataceae & Clidemia hirta & 0,56 & 2,07 & 2,63 \\
Apiaceae & Centella asiatica & 1,39 & 2,07 & 3,46 \\
Fabaceae & Mimosa pudica & 0,37 & 1,48 & 1,85 \\
Convovulaceae & Ipomoea batatas & 0,15 & 0,29 & 0,44 \\
Cannaceae & Canna discolor & 0,11 & 0,59 & 0,7 \\
\hline 22 Suku & 45 Spesies & & & \\
\hline
\end{tabular}

nilai dominansi akan meningkat. Pada tabel di atas tumbuhan herba sangat didominasi oleh jenis Lophatherium gracile, Brachiaria decumbens, Chromolaena odorata, dan Asystasia gangetica.

Tingkat kemerataan tumbuhan herba Blok Pemanfataan Sumber Agung Resort Tahura Wan Abdul Rachman Lampung termasuk dalam kategori rendah. Hal ini terjadi karena terdapat jenis yang lebih dominan di suatu komunitas. Ketersediaan pemanfaatan nutrisi yang berbeda menyebabkan tingkat keanekaragaman dan tingkat kemerataan tumbuhan di suatu tempat menjadi bervariasi (Soerianegara dan Indrawan, 1982).

Analisis Hasil Indeks Nilai Penting (INP) tumbuhan herba di Blok Pemanfataan Sumber Agung Resort Tahura Wan Abdul Rachman Lampung. Menunjukkan bahwa keempat jenis tersebut cenderung mendominasi pada setiap titik pengamatan, sesuai dengan pernyataan Syafei (1977) bahwa dari 4 jenis tumbuhan dengan indeks nilai penting terbesar dapat dipergunakan untuk menentukan suatu komunitas tumbuhan.

Indeks Nilai Penting (INP) digunakan untuk menggambarkan tingkat penguasaan suatu jenis terhadap komunitas, semakin besar nilai INP suatu jenis maka semakin besar tingkat penguasaan terhadap komunitas dan sebaliknya (Saharjo dan Cornelio, 2011). Jenis yang mendominasi pada suatu habitat dipengaruhi oleh beberapa faktor antara lain yaitu persaingan antara tumbuhan yang ada, dalam hal ini berkaitan dengan mineral atau zat hara yang diperlukan, jika mineral atau zat hara dibutuhkan mendukung maka jenis tersebut akan lebih mendominasi dan lebih banyak ditemukan (Syafei, 1977). Persaingan akan meningkatkan daya saing untuk mempertahankan hidup, jenis yang kuat akan menekan yang lain sehingga jenis yang kalah menyebabkan tingkat reproduksi rendah dan kepadatannya sedikit.

Magurran (1988) menjelaskan bahwa Nilai Indeks Keanekaragaman ( $\left.\mathrm{H}^{\prime}\right)$ berhubungan dengan kekayaan spesies pada lokasi tertentu, tetapi dipengaruhi oleh distribusi kelimpahan spesies. Semakin tinggi nilai indeks $\left(H^{\prime}\right)$ maka semakin tinggi pula keanekaragaman spesies dan kestabilan ekosistem. Kekayaan jenis adalah jumlah jenis dalam suatu komunitas. Semakin banyak jumlah jenis yang ditemukan maka indeks kekayaannya juga semakin besar. Jika pertambahan jumlah spesies berbanding terbalik dengan pertambahan jumlah inividu. Hal ini menunjukkan bahwa biasanya pada suatu komunitas atau ekosistem yang memiliki banyak spesies akan memiliki sedikit jumlah individu pada setiap spesies tersebut.

Magurran (1988) menjelaskan bahwa Nilai Indeks Keanekaragaman (H') berhubungan dengan kekayaan spesies pada lokasi tertentu, tetapi dipengaruhi oleh distribusi kelimpahan spesies. Semakin tinggi nilai indeks ( $\left.H^{\prime}\right)$ maka semakin tinggi pula keanekaragaman spesies dan kestabilan ekosistem. Kekayaan jenis adalah jumlah jenis dalam suatu komunitas. Semakin banyak jumlah jenis yang ditemukan maka indeks kekayaannya juga semakin besar. Jika pertambahan jumlah spesies berbanding terbalik dengan pertambahan jumlah inividu. Hal ini menunjukkan bahwa biasanya pada suatu komunitas atau 
ekosistem yang memiliki banyak spesies akan memiliki sedikit jumlah individu pada setiap spesies tersebut.

Faktor abiotik pada penelitian ini yaitu suhu udara, $\mathrm{pH}$ tanah, dan kelembaban tanah. Hasil analisis di Blok Pemanfataan Sumber Agung Resort Taman Hutan Raya Wan Abdul Rachman Lampung menunjukkan bahwa suhu udara sebesar $26^{\circ} \mathrm{C}-28^{\circ} \mathrm{C}, \mathrm{pH}$ tanah sebesar $5,4-5,9$. Dan kelembaban tanah 50\% - 70\%. Hasil pengukuran suhu udara $26^{\circ} \mathrm{C}-28^{\circ} \mathrm{C}$ menunjukkan bahwa suhu mempengaruhi proses pertumbuhan. Selanjutnya $\mathrm{pH}$ tanah sebesar 5,4 - 5,9 berada pada kondisi sedikit basa hingga netral. Pada umumnya tumbuhan dapat tumbuh pada pH antara 5,0 - 8,0 (Kartaspoetra,2006).

Peranan tumbuhan herba bagi hutan adalah menjaga keseimbangan ekosistem, memperkuat struktur tanah hutan, membantu menahan jatuhnya air secara langsung, dan menghambat atau mencegah erosi yang berlangsung secara cepat, tumbuhan ini dapat menghalangi jatuhnya air hujan secara langsung dan mendorong perkembangan biota tanah yang dapatmemperbaiki sifat fisik dan kimia tanah serta berperan dalam menambah bahan organik tanah (Maisyaroh,2010).

\section{KESIMPULAN}

Berdasarkan hasil penelitian ini diperoleh kesimpulan bahwa terdapat 45 jenis tumbuhan herba yang telah diidentifikasi, terdiri dari 22 suku. Jenis tumbuhan herba yang kerapatannya terbanyak yaitu terapat pada suku Asteraceae, Solanaceae, Araceae, Poaceae, Zingiberaceae, dan Euphorbiaceae. Selain itu, karakteristik pertumbuhan herba di pengaruhi oleh suhu udara, kelembaban tanah dan $\mathrm{pH}$ tanah dan Indeks Nilai Penting (INP) pada tumbuhan herba tertinggi yaitu pada Suku Poaceae jenis Lophatherium gracile dengan indeks nilai penting (INP) sebesar 31,43\%.

\section{SARAN}

Berdasarkan hasil penelitian dapat diketahui jenis tumbuhan herba yang beranekaragam, berarti di Blok
Pemanfataan Sumber Agung Resort Taman Hutan Raya Wan Abdul Rachman Lampung memiliki keanekaragaman sumber daya alam hayati dan memiliki nilai tambah untuk pengembangan bidang penelitian.

\section{DAFTAR PUSTAKA}

Ariningsih, R. (2009). Isolasi Streptomyces Dari Rizosfer Familia Poaceae Yang Berpotensi Menghasilkan Anti jamur Terhadap Candida albicans (Skripsi). Tersedia dari Electronic Theses and Dissertations UMS. (UMS No. 3397).

Arsyah, C Disca. (2014). Kajian Etnobotani Tanaman Herbal dan Pemanfaatannya dalam Usaha Menunjang Kesehatan Keluarga di Dusun Turgo, Purwobinangun, Pakem, Sleman (Skripsi). Tersedia dari Instutional Repository UIN Sunan Kalijaga Yogyakarta. (UINSK No 13221).

Aththorick, T. A., Widhiastuti, R., dan Evanus, A. (2006). Studi keanekaragaman pohon pada tiga zona ketinggian hutan pegunungan Gunung Sinabung Kabupaten Karo. Jurnal Komunikasi Penelitian, 18(3), 32-39.

Cronquist, A. (1981). An Integrated System of Classification of Flowering Plant. New York: Columbia University.

Dinas Kehutanan Provinsi Lampung. (2006). Master Plant Taman Hutan Raya (TAHURA) Wan Abdul Rachman. Jakarta: PT. Laras Sembada.

Duke, J. A. (2001). Handbook of Edible Weeds. London: CRC Press.

Fachrul, M. F. (2007). Metode Sampling Bioekologi. Jakarta: Bumi Aksara.

Heddy S., Soemitro, S.B., dan S. Soekartomo. (1986). Pengantar Ekologi. Jakarta: Rajawali.

Holtum, R.E. (1989). A Revised Flora of Malaya Vol. II. Fern of Malayan. Singapore : Govermen Printing Office. 
Indriyanto. (2006). Ekologi Hutan. Jakarta: PT. Bumi Aksara.

Magurran, A. E. (1988). Ecological diversity and its measurement. New Jersey: Princeton University Press.

Maysaroh. (2010). Struktur Komunitas Tumbuhan Penutup Tanah di Taman Hutan Raya R. Soerjo Cangar, Malang. Jurnal Pembangunan Alam Lestari, 1(1).

Ramazas. (2012). Ekologi Umum Edisi Kedua. Yogyakarta: Gadjah Mada University Press.

Saharjo, B. H. Dan Cornelio G. (2011). Suksesi Alami Paska Kebakaran pada Hutan Sekunder di Desa Fatuquero, kecamatan Railaco, Kabupaten Ermera Timor Leste. Jurnal Silvikultur Trofika, 2(1), 40-45.
Soegianto ,A. (1994). Ekologi Kuantitatif : Metode analisis populasi dan komunitas. Surabaya: Usaha Nasional.

Soerianegara, I. Indrawan. (1982). Ekologi Hutan Indonesia. Departemen Manajemen Hutan. Bogor: Fakultas Kehutanan Institut Pertanian Bogor.

Steenis, C.G.J Van. (2006). Flora Pegunungan Jawa. Bogor: Pusat Penelitian Biologi LIPI.

Syafei, E.S. (1990). Pengantar Ekologi Tumbuhan. Bandung: Institut Teknologi Bandung.

Tjitrosoepomo. (2003). Morfologi Tumbuhan. Yogyakarta: Gadjah Mada University Press.

Wright, S. J. (2002). Plant Diversity Tropical Foresta Review of Mechanism of Spesies Coexistence. Jurnal Oecologia, 130, 1-1. 